\title{
Understanding phase-transfer catalytic synthesis of fullerenol and its interference from carbon dioxide and ozone
}

\author{
Sirikanya Chokaouychai ${ }^{1,2}$ (C) Qi Zhang ${ }^{1,3,4} \oplus$
}

Received: 27 May 2020 / Accepted: 3 September 2020 / Published online: 21 September 2020

(c) The Author(s) 2020

\begin{abstract}
Phase-transfer catalytic reaction involving the use of tetrabutylammonium hydroxide (TBAH) as catalyst and sodium hydroxide $(\mathrm{NaOH})$ solution as the source of hydroxide ions is among the popular choices for synthesis of fullerenol, the polyhydroxylated fullerene. To further understand the process, two experiments were conducted to preliminarily explore the influences of the amount of TBAH and $\mathrm{NaOH}$, respectively, in terms of the achieved level of hydroxylation (i.e. number of hydroxyl groups per fullerenol molecule). The process responded to the variation of the amount of TBAH (over a twofold series of 3-192 drops, average volume $0.0223 \pm 0.0004 \mathrm{ml}$ per drop) in a nonlinear manner with a local maximum achieved from 24 drops TBAH (giving $13 \mathrm{OH}$ groups) and a local minimum from 48 drops (giving 8 groups). To the variation of the amount of $\mathrm{NaOH}$ (over the range of $0.5-8.0 \mathrm{ml} \mathrm{NaOH}$ ), the fitted function of the process response resembled Freundlich adsorption isotherm, with an initially increasing trend before levelling off at $4.0 \mathrm{ml}$ $\mathrm{NaOH}$ (giving $15 \mathrm{OH}$ groups). It is therefore suggested that fullerene hydroxylation could be explained by liquid-solid adsorption. In addition, it was found that ambient carbon dioxide led to the existence of sodium carbonate in the bulk of the collected product (although not chemically bound). It was also discovered that ambient ozone adversely affected fullerenol synthesis by converting $\mathrm{C}_{60}$ fullerene into fullerene epoxide $\left(\mathrm{C}_{60} \mathrm{O}\right)$. The affected syntheses thus produced epoxide-containing fullerenol instead.
\end{abstract}

Keywords Fullerenol · Carbon nanomaterials · TBAH · Ozone $\cdot$ Carbon dioxide · Fullerene epoxide

Qi Zhang

mkzhang59@gmail.com

Extended author information available on the last page of the article 


\section{Introduction}

Since the great discovery by Kroto et al. in 1985 [1], $\mathrm{C}_{60}$ fullerene (also 'Buckminsterfullerene') has been heavily investigated on its properties, as well as potential applications which extends to cover a variety of fields. However, applications of $\mathrm{C}_{60}$ fullerene in biomedical conditions had been limited due to its hydrophobicity. In order to eliminate this limitation, water-soluble fullerene derivatives have been synthesised and one of the most popular is the hydroxylated fullerene or 'fullerenol' [2].

The first few reports on successful synthesis of fullerenol dated back in 1992 $[3,4]$. To date, there are several different methods to produce fullerenol from $\mathrm{C}_{60}$ fullerene, which vary in terms of reaction conditions, complexity, duration and operational safety [5-9]. One of the most frequently selected methods for the synthesis of fullerenol is the hydroxylation of fullerene through phase-transfer catalysis using tetrabutylammonium hydroxide (TBAH) as phase-transfer catalyst and sodium hydroxide $(\mathrm{NaOH})$ solution as the source of hydroxide ions, reported by Li et al. [5]. The process appears rather simple and safe for operation, compared to several other alternatives. Nevertheless, the process still has not been thoroughly studied or understood.

A good understanding of the production of any type of material is crucial for its further research and development. This study therefore conducted preliminary experiments to gain further understanding of the process. The study focused on the process response (in terms of the achieved level of hydroxylation, i.e. number of hydroxyl groups successfully added onto the fullerene molecule) to the amount of phase-transfer catalyst TBAH and the amount of the source of hydroxide ions. Problems associated with contamination from unwanted reactions with carbon dioxide and ozone (previously published as an abstract for a conference [10]) arose during the time when the experiments were conducted and are also discussed in this article. The discovered phenomena formed important bases for the establishment of precautions for the process.

\section{Experimental}

\section{Chemicals}

Fullerene $\left(\mathrm{C}_{60}, 99.5 \%\right)$ and toluene $\left(\mathrm{C}_{7} \mathrm{H}_{8}\right.$, ACS reagent grade $)$ were purchased from Sigma-Aldrich. Sodium hydroxide pellets $(\mathrm{NaOH}, 98.50 \%)$, tetrabutylammonium hydroxide (TBAH; $\mathrm{C}_{16} \mathrm{H}_{37} \mathrm{NO} ; 40 \%$ in water) and methanol $\left(\mathrm{CH}_{3} \mathrm{OH}\right.$; HPLC grade) were purchased from Acros Organics, Fluka Analytical and Fisher Scientific, respectively. 


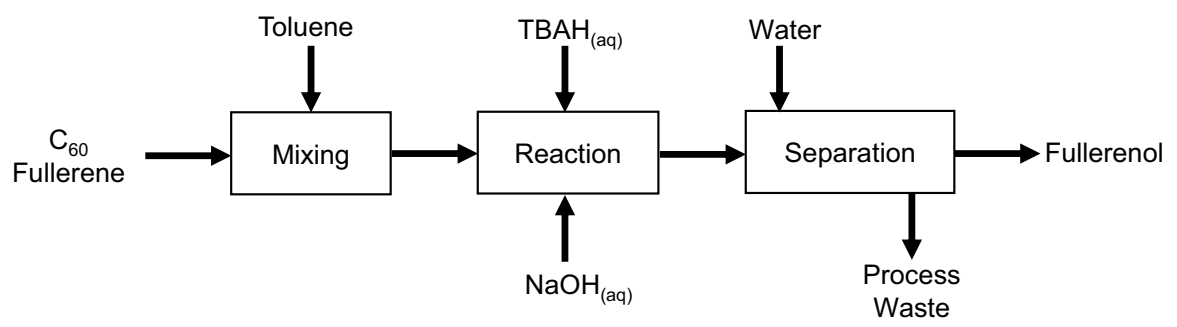

Fig. 1 Simplified block flow diagram for phase-transfer catalytic synthesis of fullerenol

\section{Influence of TBAH on the achieved level of hydroxylation}

The synthesis method used to produce fullerenol (Fig. 1) is a modified version of the method reported by $\mathrm{Li}$ et al. [5]. In general, $\mathrm{C}_{60}$ fullerene $(80 \mathrm{mg})$ was dissolved into toluene $(60 \mathrm{ml})$ using ultrasonication to give a clear purple solution. TBAH was added to the solution using a Pasteur pipette, followed by the addition of $100 \% \mathrm{~W} / \mathrm{V}$ sodium hydroxide solution $(2 \mathrm{ml})$. The resulting mixture was then vigorously stirred for $20 \mathrm{~min}$ at room temperature using a magnetic stirrer. Once achieved, toluene was evaporated off the mixture using a rotary evaporator. De-ionised water $(10 \mathrm{ml})$ was then added, and the diluted mixture was moderately stirred at room temperature for $12 \mathrm{~h}$. Upon completion, additional $20 \mathrm{ml}$ de-ionised water was added to the mixture prior to the removal of water-insoluble solids through vacuum filtration with nylon- 6,6 membrane $(0.45 \mu \mathrm{m}$ pore size; Fluka Analytical). The filtrate was concentrated and then added with methanol $(40 \mathrm{ml})$ to give red-brown precipitate. Precipitation was repeated once more, and the final precipitate retained on the filter membrane was oven-dried below $80^{\circ} \mathrm{C}$ for 30 min to obtain brown powder. The product was stored in a cool and dry place, away from sunlight, and in a tightly sealed container.

To investigate the influence of TBAH on the achieved level of hydroxylation, seven fullerenols were produced using different amounts of TBAH: 3, 6, 12, 24, 48, 96 and 192 drops for Products 1-7, respectively. It was determined that the average mass of a single drop of TBAH solution (density $0.995 \mathrm{~g} / \mathrm{ml}$ ) from the Pasteur pipette of the same manufacturer and model was $0.0222 \pm 0.0004 \mathrm{~g}$ ( $95 \%$ confidence interval, 30 samples). Each drop of TBAH solution is therefore equivalent to the volume of $0.0223 \pm 0.0004 \mathrm{ml}$.

\section{Influence of sodium hydroxide on the achieved level of hydroxylation}

In this experiment, the influence of sodium hydroxide on the achieved level of hydroxylation was investigated by varying the amount of sodium hydroxide solution used in the synthesis method described in the first paragraph of "Influence of TBAH on the achieved level of hydroxylation" section. Five different fullerenols, Product 8 to Product 12, were synthesised using $0.5,1.0,2.0,4.0$ and $8.0 \mathrm{ml}$ sodium hydroxide solution $(100 \% \mathrm{~W} / \mathrm{V})$, respectively. All syntheses used 24 drops of TBAH solution. 


\section{Material characterisation}

Fourier transform infrared (FTIR) spectroscopy was used to verify chemical identity. The sample was finely ground together with dried potassium bromide $(\mathrm{KBr})$ powder. The resulting mixed powder was pressed using high pressure to form a disc, which was then placed into the measurement chamber of an ALPHA (Bruker) spectrometer. All measurements were taken under transmission mode with $4000-400 \mathrm{~cm}^{-1}$ range.

XL30 (Philips) scanning electron microscope (SEM) was used to produce low-magnification electron micrographs. Each sample was sprinkled onto a stud (thinly pre-coated with silver dag). The SEM was equipped with INCA X-sight (Oxford Instrument) energy-dispersive X-ray (EDX) spectroscopy for elemental analysis function.

Information on loss of mass against temperature was monitored and recorded using a TG50 (Mettler Toledo) thermogravimetric analysis (TGA) instrument. For each TGA measurement, the sample (approximately $5 \mathrm{mg}$ ) was put into an alumina crucible (with lid), which was then placed onto the sample pan vertically connected to the hanging balance of the instrument. All measurements were taken under the same conditions: nitrogen atmosphere, $10{ }^{\circ} \mathrm{C} / \mathrm{min}$ heating rate and $50-1000{ }^{\circ} \mathrm{C}$ range [11].

\section{Level of hydroxylation}

In this research, we define 'level of hydroxylation' as the average number of hydroxyl groups $(\mathrm{OH})$ successfully added onto a fullerene molecule as a result of fullerene hydroxylation reaction. The following systemic process to estimate the achieved level of hydroxylation was adapted from the method used by Kokubo et al. in 2008 and 2011 [9, 12] to derive chemical formula of fullerenol.

For each product, all characterisation results were used to define the plausible chemical formula (and to determine whether any other chemical species were also present). In general, the chemical formula of fullerenol (contaminationfree) was assumed to be ' $a \mathrm{C}_{60}(\mathrm{OH})_{n} \cdot b \mathrm{H}_{2} \mathrm{O}$ '. The percentage of physically bound water molecules in the product was determined from the first weight loss (below $180{ }^{\circ} \mathrm{C}$ ) in a TGA thermogram. The number was then converted into the number of moles. From EDX results, elemental percentages were also converted into number of moles. Based on the defined plausible chemical formula and information on number of moles of other chemical species present, a system of simultaneous equations was established, linking all information together. By solving the simultaneous equations, values of the variables (i.e. numbers of moles) could be determined. 


\section{Percent yield}

Percent yield and theoretical yield of each synthesis could be approximately estimated from Eqs. 1 and 2, respectively [13]:

$$
\begin{gathered}
\text { Percent Yield }=\frac{\text { Actual Yield }}{\text { Theoretical Yield }} \times 100 \\
\text { Theoretical Yield }=\frac{M_{\mathrm{p}}}{M_{\mathrm{C}_{60}}} \times m_{\mathrm{C}_{60}}
\end{gathered}
$$

where $M_{\mathrm{p}}$ refers to molar mass of product (based on the determined chemical formula), $M_{\mathrm{C}_{60}}$ refers to molar mass of a $\mathrm{C}_{60}$ molecule and $m_{\mathrm{C}_{60}}$ refers to mass of $\mathrm{C}_{60}$ used for the synthesis.

\section{Results and discussion}

\section{Phase-transfer catalytic synthesis of fullerenol with TBAH and $\mathrm{NaOH}$}

The selected method to produce fullerenol by Li et al. is a phase-transfer catalytic process with TBAH solution as the phase-transfer catalyst which enables the reaction by transporting hydroxide ions $\left(\mathrm{OH}^{-}\right)$from the aqueous phase into the organic phase (toluene) where $\mathrm{C}_{60}$ molecules exist. In addition to the phase-transfer catalyst, it has been

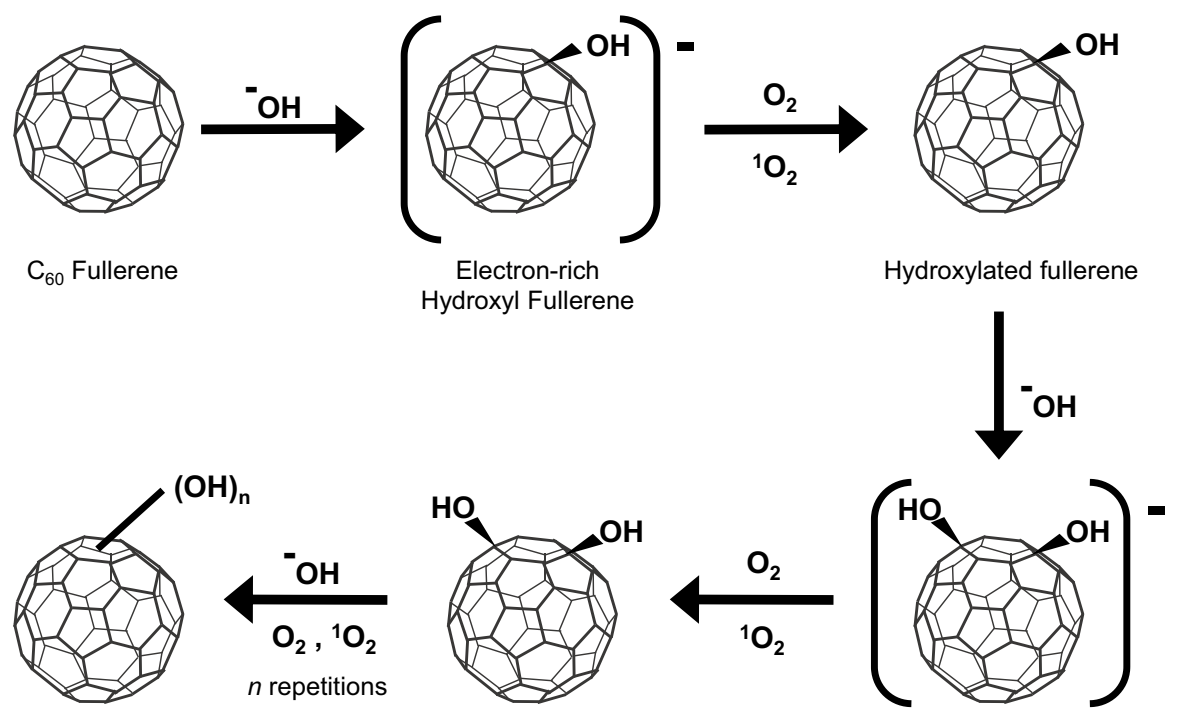

Fullerenol

Fig. 2 Fullerene hydroxylation mechanism to produce polyhydroxylated fullerene (fullerenol). Reprinted (adapted) with permission from [15] 
reported that the reaction between $\mathrm{C}_{60}$ and $\mathrm{OH}^{-}$requires the presence of oxygen gas $\left(\mathrm{O}_{2}\right)[5,9,14,15]$.

Figure 2 illustrates the possible mechanism for hydroxylation of fullerene associated with the selected synthesis route. When stimulated by light, $\mathrm{C}_{60}$ molecule, which is an excellent photosensitiser, turns into an excited triple state. Returning to its normal state, energy is released [16]. The nearby oxygen molecule $\left(\mathrm{O}_{2}\right)$ in its ground state receives this energy and transforms into singlet oxygen $\left({ }^{1} \mathrm{O}_{2}\right)$, which is required to complete the hydroxylation of fullerene. When $\mathrm{C}_{60}$ and $\mathrm{OH}^{-}$come into contact, electronrich hydroxyl fullerene is formed via nucleophilic addition. The excess electron in the electron-rich structure is taken away by ${ }^{1} \mathrm{O}_{2}$, giving hydroxylated fullerene. Repetitions of nucleophilic attack by $\mathrm{OH}^{-}$, followed by the interaction between the electron-rich complex and ${ }^{1} \mathrm{O}_{2}$ (which is described in the next paragraph), result in polyhydroxylated fullerene (fullerenol) $[15,17]$.

${ }^{1} \mathrm{O}_{2}$ is electrophilic in nature and can attract an electron from an electron-rich structure, resulting in an ion pair of a superoxide $\left(\mathrm{O}_{2}^{-}\right)$and an electron-deficit structure [18-21]. The following mechanism is proposed in this article for the interaction between ${ }^{1} \mathrm{O}_{2}$ and electron-rich hydroxyl fullerene. The electrophilic ${ }^{1} \mathrm{O}_{2}$ takes the excess electron from the electron-rich structure and becomes $\mathrm{O}_{2}^{-}$, transforming electron-rich hydroxyl fullerene into neutral hydroxylated fullerene (Fig. 3). $\mathrm{O}_{2}^{-}$in aqueous environment (TBAH and $\mathrm{NaOH}$ solutions) leads to the formation of hydrogen peroxide $\left(\mathrm{H}_{2} \mathrm{O}_{2}\right)$ and oxygen gas $\left(\mathrm{O}_{2}\right)$ via a dismutation reaction as shown in Eq. 3 [22, 23]. $\mathrm{H}_{2} \mathrm{O}_{2}$ reacts with $\mathrm{OH}^{-}$in the aqueous phase to form hydroperoxide ion $\left(\mathrm{HOO}^{-}\right)$and water as shown in Eq. 4. $\mathrm{HOO}^{-}$further reacts with $\mathrm{H}_{2} \mathrm{O}_{2}$ in the system (Eq. 5). Combination of Eqs. 4 and 5 results in the net chemical reaction in Eq. 6, with water and oxygen gas as the final products [24].

$$
\begin{gathered}
2 \mathrm{O}_{2}^{-}+2 \mathrm{H}^{+} \rightarrow \mathrm{H}_{2} \mathrm{O}_{2}+\mathrm{O}_{2} \\
\mathrm{OH}^{-}+\mathrm{H}_{2} \mathrm{O}_{2} \rightarrow \mathrm{HOO}^{-}+\mathrm{H}_{2} \mathrm{O}
\end{gathered}
$$

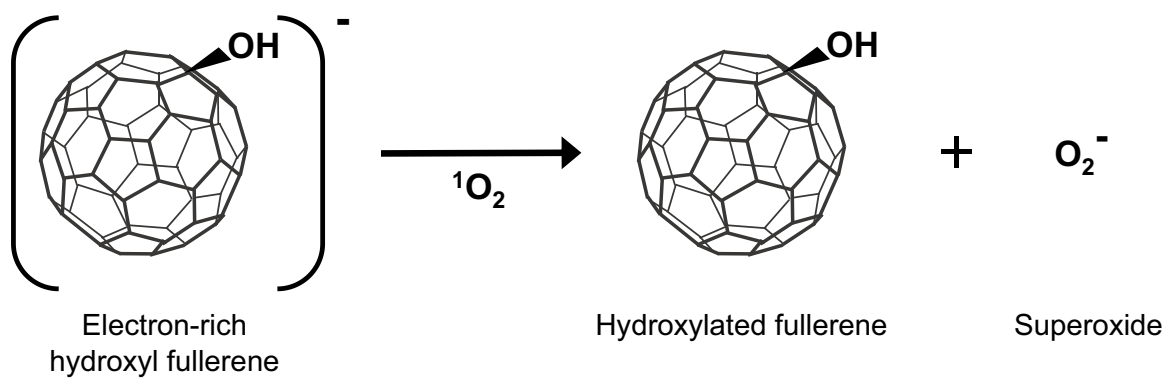

Fig. 3 Proposed reaction between singlet oxygen $\left({ }^{1} \mathrm{O}_{2}\right)$ and the electron-rich hydroxyl fullerene. Singlet oxygen, electrophilic in nature, takes an excess electron from the electron-rich hydroxyl fullerene. The electron-rich species loses an excess electron and becomes neutral, while the singlet oxygen which takes in an electron becomes a superoxide $\left(\mathrm{O}_{2}^{-}\right)[19-21]$ 


$$
\begin{gathered}
\mathrm{H}_{2} \mathrm{O}_{2}+\mathrm{HOO}^{-} \rightarrow \mathrm{H}_{2} \mathrm{O}+\mathrm{O}_{2}+\mathrm{OH}^{-} \\
2 \mathrm{H}_{2} \mathrm{O}_{2} \rightarrow 2 \mathrm{H}_{2} \mathrm{O}+\mathrm{O}_{2}
\end{gathered}
$$

\section{Influence of TBAH on the achieved level of hydroxylation}

The first experiment of this study investigated response of the described synthesis method, in terms of the achieved level of hydroxylation $(n)$, to the amount of TBAH solution added during the process. Referring to the report on the original synthesis method by Li et al. [5], the amount of TBAH solution used was described in number of drops. The variable of this experiment was therefore designed to be a series of number of drops of TBAH solution used in the process. The series (of seven data points) ranged from 3 to 192 drops $(0.0222 \pm 0.0004 \mathrm{~g}$ or $0.0223 \pm 0.0004 \mathrm{ml}$, per drop) in a twofold manner for sufficient coverage.

From the synthesis point of view, in addition to the normal observations of this method similar to the original report by $\mathrm{Li}$ et al. [5], two other unexpected phenomena were also observed and noted: (1) a small amount of fine black solids formed at the end of dissolution step and (2) trace of white, water-soluble solid on glassware surface which had come into contact with the diluted reaction mixture during separation steps. These two phenomena would be proved critical evidences later on in the discussion.

\section{Material characterisation}

All products obtained from this experiment were dark brown (Fig. 4). Infrared spectra of the products are shown in Fig. 5, where all showed absorptions characteristic to fullerenol, i.e. absorptions centred around $3430(\nu \mathrm{O}-\mathrm{H}), 1600$
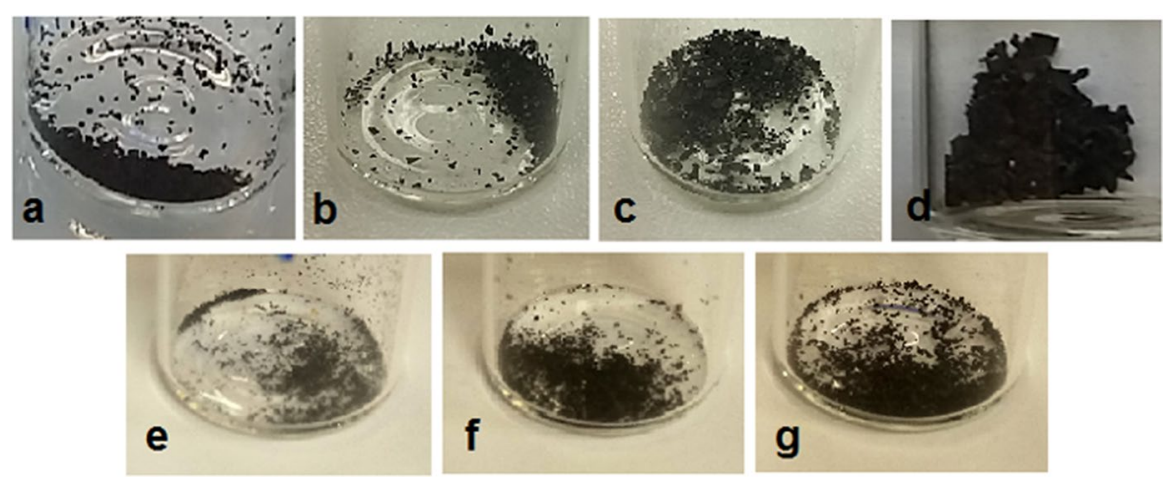

Fig. 4 Physical appearance of Products 1-7 (a-g, respectively) from fullerene hydroxylation using different amounts of TBAH solution 

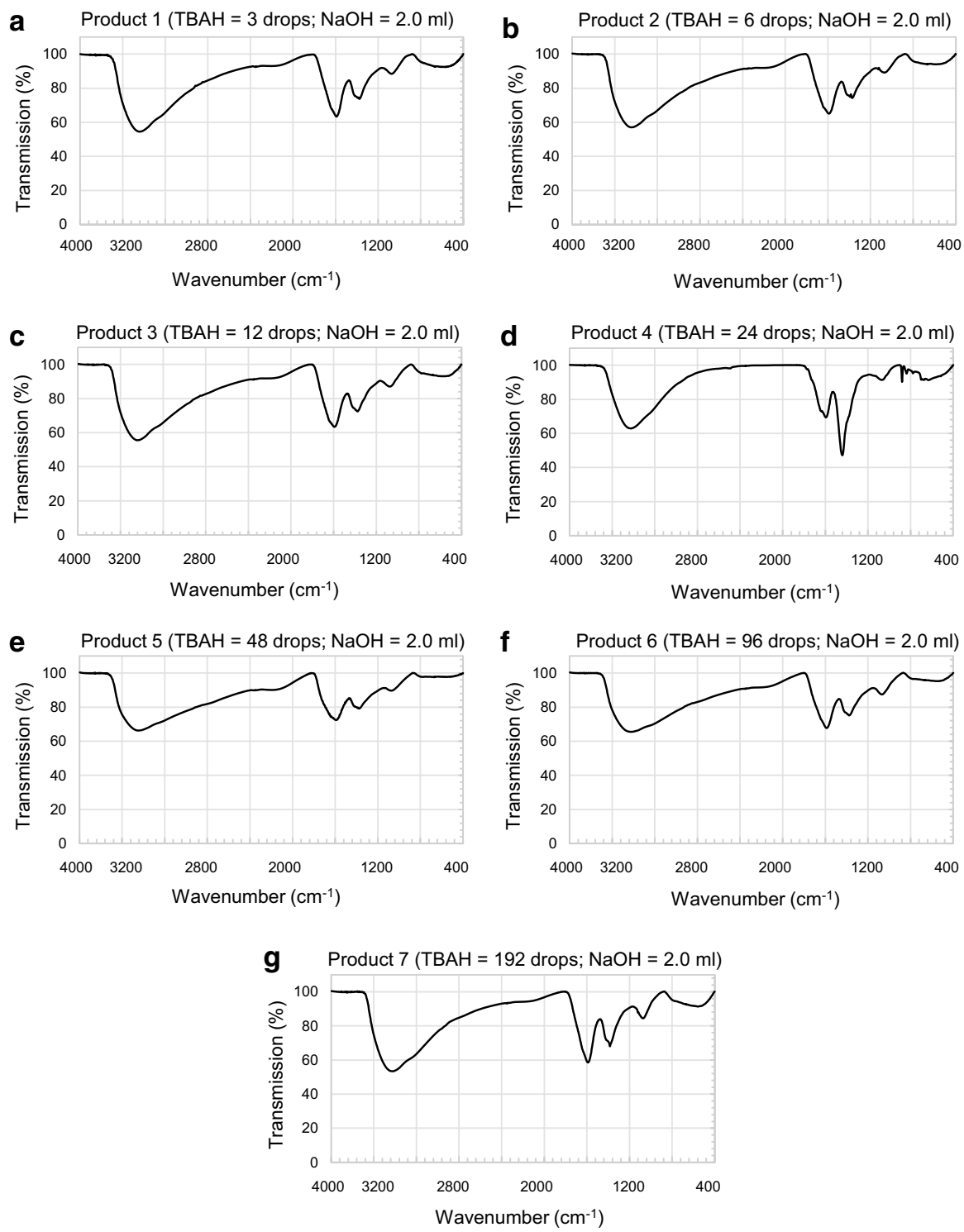

Fig. 5 Infrared spectra of fullerenols synthesised using different amounts of TBAH solution for the reaction (Products 1-7). All spectra in transmission mode

$(\nu \mathrm{C}=\mathrm{C}), 1370(\delta \mathrm{C}-\mathrm{O}-\mathrm{H})$ and $1080(\nu \mathrm{C}-\mathrm{O}) \mathrm{cm}^{-1}$. However, a 3000-2000 $\mathrm{cm}^{-1}$ broad shoulder and a small peak around $1770 \mathrm{~cm}^{-1}$ were also observed. The most unusual spectrum was shown in the case of Product 4 , where a weak peak around $880 \mathrm{~cm}^{-1}$ and the strongest absorption centring around $1440 \mathrm{~cm}^{-1}$ were present along with fullerenol absorptions. 

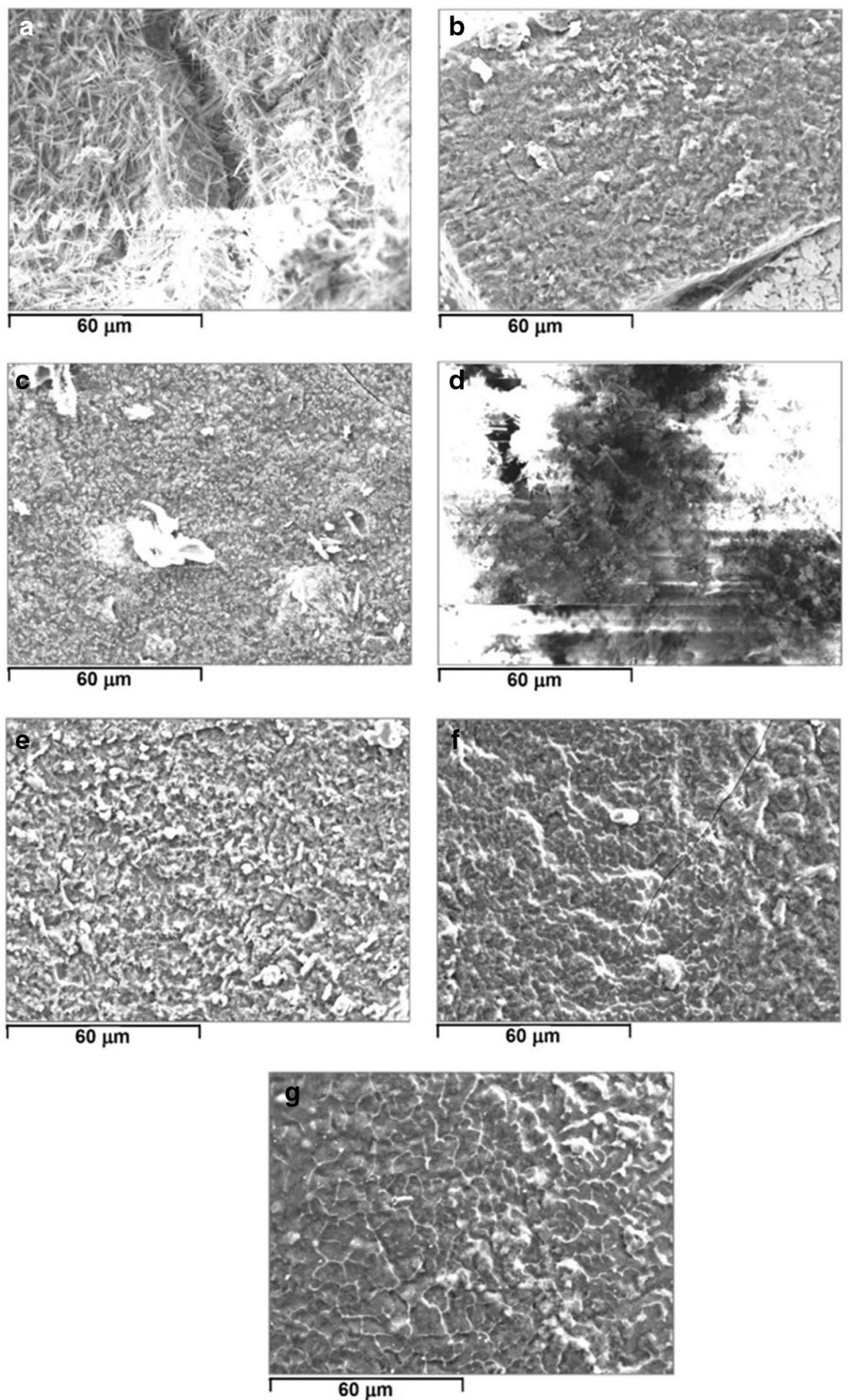

Fig. 6 Low-magnification SEM micrographs of Products 1-7 (a-g, respectively), showing pattern of solids $(\mathbf{b}, \mathbf{c}, \mathbf{e}, \mathbf{f}, \mathbf{g})$ and clear existence of needle-like objects $(\mathbf{a}, \mathbf{d})$ covering the surface of the product 
Table 1 Elemental composition of Products 1-7 obtained from EDX for carbon (C), oxygen $(\mathrm{O})$ and sodium $(\mathrm{Na})$

\begin{tabular}{lclll}
\hline Product & TBAH (drops) & $\% \mathrm{C}$ & $\% \mathrm{O}$ & $\% \mathrm{Na}$ \\
\hline 1 & 3 & 44.47 & 38.62 & 15.34 \\
2 & 6 & 43.61 & 40.25 & 14.70 \\
3 & 12 & 43.68 & 40.33 & 15.29 \\
4 & 24 & 37.49 & 42.64 & 19.15 \\
5 & 48 & 44.82 & 38.53 & 15.33 \\
6 & 96 & 49.48 & 36.78 & 13.02 \\
7 & 192 & 50.94 & 35.55 & 12.88 \\
\hline
\end{tabular}

Determining the cause of the unusual aspects from the infrared spectra required complementary results from other techniques. Low-magnification SEM micrographs (Fig. 6) show unexpected surface condition of the products. While most of the micrographs (Fig. 6b, c, e, f, g) show pattern of some solid material covering the products, Fig. 6a and $6 \mathrm{~d}$ show clear existence of needle-like objects on the surface. Analysis of EDX results (Table 1) revealed that, in addition to carbon (C) and oxygen $(\mathrm{O})$, a significant amount of sodium $(\mathrm{Na})$ was also present in all products.

Combining synthesis observations with characterisation results, it is suggested that sodium carbonate $\left(\mathrm{Na}_{2} \mathrm{CO}_{3}\right)$ might exist in all collected products, and could be of higher amount in Product 1 and Product 4 (sufficient to form needle-like crystals). Figure $5 \mathrm{~d}$ is compared against the infrared spectrum of pure $\mathrm{Na}_{2} \mathrm{CO}_{3}$ [25]. A strong absorption around $1450 \mathrm{~cm}^{-1}$ and a medium absorption around $880 \mathrm{~cm}^{-1}$ are in agreement with the $1440 \mathrm{~cm}^{-1}$ and $880 \mathrm{~cm}^{-1}$ absorptions in Fig. 5d. Nevertheless, the absorption at $880 \mathrm{~cm}^{-1}$ could have also been from another possibility-existence of epoxide groups within the products [26-32]. Further discussion on the formation of $\mathrm{Na}_{2} \mathrm{CO}_{3}$ in the process is provided in "Formation of epoxide functionality and the adverse effect of ambient ozone $\left(\mathrm{O}_{3}\right)$ to the selected synthesis method to produce fullerenol" section.

Analysing TGA thermograms of Products 1-7 (Fig. 7) against thermogravimetric behaviour of fullerenol and $\mathrm{C}_{60}$ fullerene (Fig. 8) provided further information. Thermal degradation of $\mathrm{C}_{60}$ fullerene, the parent materials, started with small and gradual loss around $670-800{ }^{\circ} \mathrm{C}$. The major loss of weight (approximately $70 \%$ ) occurred around $800-950{ }^{\circ} \mathrm{C}$ due to the sublimation of $\mathrm{C}_{60}$ fullerene [32]. A small loss around $950-1000{ }^{\circ} \mathrm{C}$ was suggested to account for degradation of $\mathrm{C}_{70}$ molecules which might be present in the starting fullerene materials as residues from fullerene manufacturing [33]. According to the previously published literature, fullerenol thermogravimetric pattern comprises [3, 11, 33]: (1) removal of physically bound water molecules (up to $180{ }^{\circ} \mathrm{C}$ ), (2) loss of hydroxyl addends (from $150{ }^{\circ} \mathrm{C}$ or $180{ }^{\circ} \mathrm{C}$ to $570{ }^{\circ} \mathrm{C}$ ) and (3) degradation of fullerene cage structure (above $650{ }^{\circ} \mathrm{C}$ ) $[3,9,11,15,32,34]$. For Products $1-7$ produced in this experiment, most products roughly followed thermogravimetric behaviour of fullerenol, except for Product 4 where (after $180{ }^{\circ} \mathrm{C}$ ) there was a large weight loss with an onset temperature around $380{ }^{\circ} \mathrm{C}$ and no clear step weight loss beyond $650{ }^{\circ} \mathrm{C}$. It was found that the weight loss around $380{ }^{\circ} \mathrm{C}$ matches with the thermogravimetric pattern of fullerene epoxide 

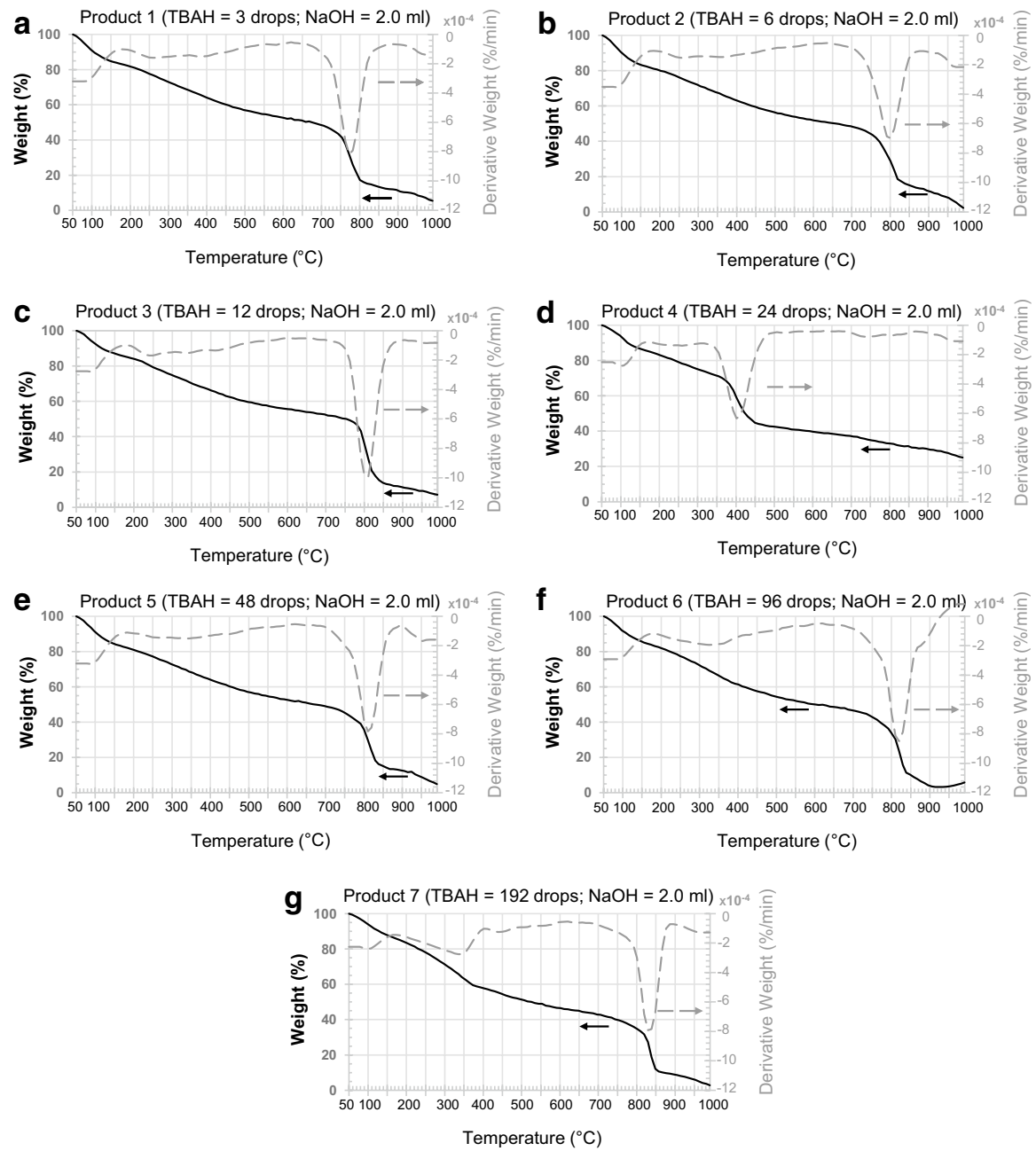

Fig. 7 TGA thermograms of Products $1-7$, respectively. The solid black lines represent TGA curves, while the dash grey lines represent the curves of the first derivative (derivative weight)

Fig. 8 TGA thermogram of pristine $\mathrm{C}_{60}$ fullerene and its first derivative (DTG) curve. The solid black line represents the TGA curve, while the dash grey line represents the curve of the first derivative (derivative weight)

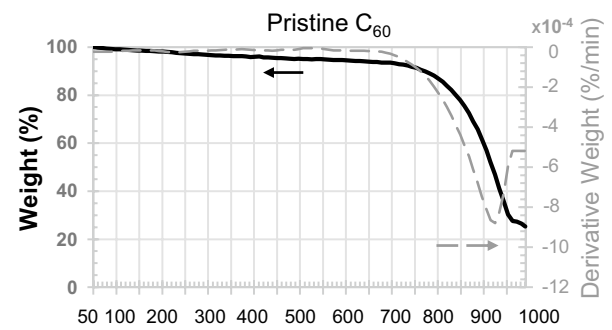

Temperature $\left({ }^{\circ} \mathrm{C}\right)$ 
$\left(\mathrm{C}_{60} \mathrm{O}\right)$ [34]. This therefore suggested that epoxide functional groups existed within Product 4 in the form of $\mathrm{C}_{60} \mathrm{O}$. The formation could have resulted from $\mathrm{C}_{60}$ fullerene coming into contact with ambient ozone $\left(\mathrm{O}_{3}\right)$ in the atmosphere of the laboratory where this research had taken place, which situates next to the room where several laser-based instruments are constantly in operation. There are three possibilities for the product from $\mathrm{C}_{60}-\mathrm{O}_{3}$ reaction: $\mathrm{C}_{60} \mathrm{O}, \mathrm{C}_{60} \mathrm{O}_{2}$ and $\mathrm{C}_{60} \mathrm{O}_{3}$. However, the latter two scenarios were not considered in this preliminary analysis due to the fact that they only exist in very small percentages when compared to $\mathrm{C}_{60} \mathrm{O}$ [34].

Based on the analysis of characterisation results, all products were fullerenol, with coexistence of $\mathrm{Na}_{2} \mathrm{CO}_{3}$ solids, but not structurally incorporated. For Product 4 , the fullerenol also contained epoxide groups in addition to the desired hydroxyl groups.

\section{TBAH and level of hydroxylation}

Taking into account the non-binding coexistence of $\mathrm{Na}_{2} \mathrm{CO}_{3}$ in all products, to estimate the average number of hydroxyl groups successfully added to a fullerene molecule from each product, i.e. the achieved level of hydroxylation $(n)$, the products were assumed to have chemical formula in the form of ' $a \mathrm{C}_{60}(\mathrm{OH})_{n} \cdot b \mathrm{H}_{2} \mathrm{O}$ with $\mathrm{cNa}_{2} \mathrm{CO}_{3}$ ' where the variables ' $a$ ', ' $b$ ' and ' $c$ ' represents the number of moles of $\mathrm{C}_{60}(\mathrm{OH})_{n}, \mathrm{H}_{2} \mathrm{O}$ and $\mathrm{Na}_{2} \mathrm{CO}_{3}$, respectively. An exception was for Product 4 where epoxide groups were also present in the fullerenol molecule. Therefore, its associated chemical formula was ' $a \mathrm{C}_{60} \mathrm{O}(\mathrm{OH})_{n} \cdot b \mathrm{H}_{2} \mathrm{O}$ with $c \mathrm{Na}_{2} \mathrm{CO}_{3}$.

Following the method described in "Level of hydroxylation" section, chemical formulae for Products 1-7 have been calculated and are shown in Table 2 along with relevant compositional analysis.

Table 2 Calculated chemical formulae for Products 1-7 with corresponding weight percentages of $\mathrm{C}_{60}(\mathrm{OH})_{n}, \mathrm{H}_{2} \mathrm{O}$ and $\mathrm{Na}_{2} \mathrm{CO}_{3}$ components and calculated elemental percentages for $\mathrm{C}, \mathrm{O}, \mathrm{Na}$ and $\mathrm{H}$

\begin{tabular}{|c|c|c|c|c|c|c|c|c|}
\hline Product & Chemical formula & $\%$ wt $\mathrm{C}_{60}(\mathrm{OH})_{n}$ & $\%$ wt $\mathrm{H}_{2} \mathrm{O}$ & $\%$ wt $\mathrm{Na}_{2} \mathrm{CO}_{3}$ & $\% \mathrm{C}$ & $\% \mathrm{O}$ & $\% \mathrm{Na}$ & $\% \mathrm{H}$ \\
\hline 1 & $\begin{array}{l}\mathrm{C}_{60}(\mathrm{OH})_{9} \cdot 7 \mathrm{H}_{2} \mathrm{O} \text { with } \\
6 \mathrm{Na}_{2} \mathrm{CO}_{3}\end{array}$ & 48.10 & 16.86 & 35.04 & 43.64 & 38.79 & 15.21 & 2.37 \\
\hline 2 & $\begin{array}{c}\mathrm{C}_{60}(\mathrm{OH})_{10} \cdot 19 \mathrm{H}_{2} \mathrm{O} \\
\text { with } 6 \mathrm{Na}_{2} \mathrm{CO}_{3}\end{array}$ & 47.64 & 18.31 & 34.05 & 42.40 & 40.26 & 14.78 & 2.57 \\
\hline 3 & $\begin{array}{c}\mathrm{C}_{60}(\mathrm{OH})_{13} \cdot 15 \mathrm{H}_{2} \mathrm{O} \\
\text { with } 7 \mathrm{Na}_{2} \mathrm{CO}_{3}\end{array}$ & 48.18 & 13.82 & 38.99 & 41.17 & 40.14 & 16.49 & 2.20 \\
\hline 4 & $\begin{array}{c}\mathrm{C}_{60} \mathrm{O}(\mathrm{OH})_{13} \cdot 19 \mathrm{H}_{2} \mathrm{O} \\
\text { with } 10 \mathrm{Na}_{2} \mathrm{CO}_{3}\end{array}$ & 40.59 & 14.49 & 44.93 & 35.59 & 42.71 & 19.49 & 2.20 \\
\hline 5 & $\begin{array}{l}\mathrm{C}_{60}(\mathrm{OH})_{8} \cdot 18 \mathrm{H}_{2} \mathrm{O} \text { with } \\
6 \mathrm{Na}_{2} \mathrm{CO}_{3}\end{array}$ & 47.14 & 17.84 & 35.02 & 43.61 & 38.77 & 15.20 & 2.42 \\
\hline 6 & $\begin{array}{l}\mathrm{C}_{60}(\mathrm{OH})_{9} \cdot 15 \mathrm{H}_{2} \mathrm{O} \text { with } \\
5 \mathrm{Na}_{2} \mathrm{CO}_{3}\end{array}$ & 52.18 & 16.14 & 31.68 & 46.62 & 37.30 & 13.75 & 2.33 \\
\hline 7 & $\begin{array}{c}\mathrm{C}_{60}(\mathrm{OH})_{10} \cdot 12 \mathrm{H}_{2} \mathrm{O} \\
\text { with } 5 \mathrm{Na}_{2} \mathrm{CO}_{3}\end{array}$ & 54.40 & 13.20 & 32.40 & 47.68 & 36.19 & 14.06 & 2.08 \\
\hline
\end{tabular}


Table 3 Theoretical yield (mg), actual yield (mg) and the estimated percent yield for Products 1-7

\begin{tabular}{lclccr}
\hline Product & TBAH (drops) & Chemical formula & $\begin{array}{l}\text { Theoretical } \\
\text { yield }(\mathrm{mg})\end{array}$ & \multicolumn{1}{l}{$\begin{array}{l}\text { Actual } \\
\text { yield }(\mathrm{mg})\end{array}$} & $\%$ Yield \\
\hline 1 & 3 & $\mathrm{C}_{60}(\mathrm{OH})_{9} \cdot 7 \mathrm{H}_{2} \mathrm{O}$ with $6 \mathrm{Na}_{2} \mathrm{CO}_{3}$ & 97.0 & 7.7 & 8.0 \\
2 & 6 & $\mathrm{C}_{60}(\mathrm{OH})_{10} \cdot 19 \mathrm{H}_{2} \mathrm{O}$ with $6 \mathrm{Na}_{2} \mathrm{CO}_{3}$ & 99.4 & 9.6 & 9.7 \\
3 & 12 & $\mathrm{C}_{60}(\mathrm{OH})_{13} \cdot 15 \mathrm{H}_{2} \mathrm{O}$ with $7 \mathrm{Na}_{2} \mathrm{CO}_{3}$ & 106.1 & 30.7 & 29.0 \\
4 & 24 & $\mathrm{C}_{60} \mathrm{O}(\mathrm{OH})_{13} \cdot 19 \mathrm{H}_{2} \mathrm{O}$ with $10 \mathrm{Na}_{2} \mathrm{CO}_{3}$ & 111.0 & 71.0 & 63.9 \\
5 & 48 & $\mathrm{C}_{60}(\mathrm{OH})_{8} \cdot 18 \mathrm{H}_{2} \mathrm{O}$ with $6 \mathrm{Na}_{2} \mathrm{CO}_{3}$ & 95.9 & 8.8 & 9.2 \\
6 & 96 & $\mathrm{C}_{60}(\mathrm{OH})_{9} \cdot 15 \mathrm{H}_{2} \mathrm{O}$ with $5 \mathrm{Na}_{2} \mathrm{CO}_{3}$ & 98.0 & 17.7 & 18.1 \\
7 & 192 & $\mathrm{C}_{60}(\mathrm{OH})_{10} \cdot 12 \mathrm{H}_{2} \mathrm{O}$ with $5 \mathrm{Na}_{2} \mathrm{CO}_{3}$ & 99.1 & 19.9 & 20.1 \\
\hline
\end{tabular}

From a manufacturing point of view, percent yield is also an important aspect to understand about the selected fullerenol synthesis method in addition to the level of hydroxylation. However, as the reaction is still not fully understood and the exact stoichiometry has not been revealed yet, modification to the conventional percent yield calculation was necessary. Following the method described in "Percent yield" section, the values of calculated percent yield for Products 1-7, along with associated information, are listed in Table 3.

Values of the calculated level of hydroxylation and percent yield are plotted against the corresponding amount of TBAH solution used for specific synthesis, as shown in Fig. 9. Both data exhibit nonlinear relationships. In terms of level of hydroxylation, the observed nonlinear pattern starts with an upward trend towards a maximum at $\mathrm{TBAH}=24$ drops. Once past the maximum, there is a sharp drop towards a minimum at $\mathrm{TBAH}=48$ drops. Increasing the amount of TBAH solution used in the process beyond 48 drops (96 and 192 drops) slightly raises the achieved level of hydroxylation, but still distinctively lower than the maximum. Similar pattern is observed in the case of percent yield; however, it is dramatically less responsive to the increased amount of TBAH solution used beyond 48 drops. Considering both aspects, it could be said that, within the experimented range, using 24 drops of TBAH solution produces the optimum results in terms of both level of hydroxylation and percent yield.

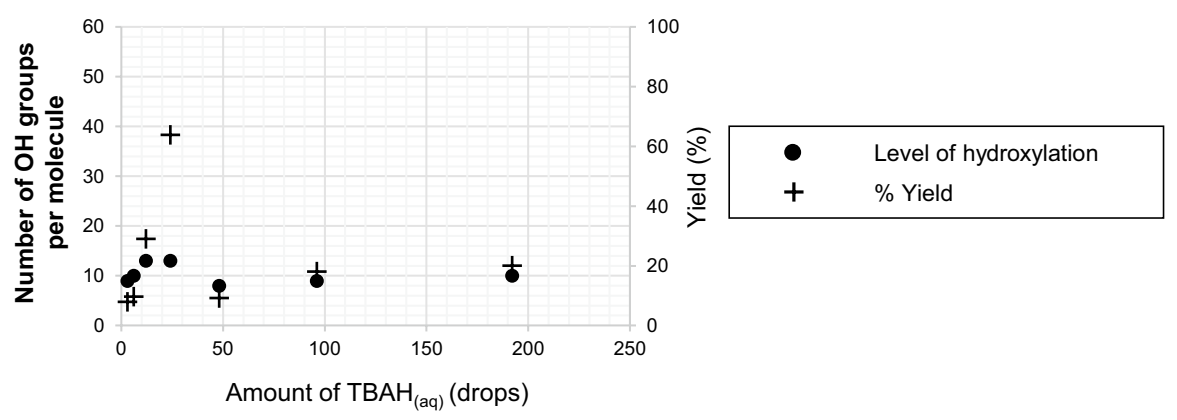

Fig. 9 Plots for level of hydroxylation (dots) and percent yield (crosses) against the amount of TBAH solution used 


\section{Influence of $\mathrm{NaOH}$ on the achieved level of hydroxylation}

Based on the same fullerenol synthesis method, this experiment explored the effect of $\mathrm{NaOH}$ on the achieved level of hydroxylation by varying volume of $\mathrm{NaOH}$ solution, the source of hydroxide ions, used in the process. The series of variable (volume of $\mathrm{NaOH}$ solution) was also a twofold series, starting from 0.5 to $8 \mathrm{ml}$ (five data points).

Ideally, variation of concentration should be applied in order to avoid errors on the total volume of the reaction mixture. Nevertheless, such concept encountered some practical limitations which prevented effective operation and could lead to more severe errors. Considering the facts that the volume of $\mathrm{NaOH}$ solution $(100 \%$ W/V) used in the original synthesis is $20 \mathrm{ml}$ [5] and that solubility of $\mathrm{NaOH}$ at $20{ }^{\circ} \mathrm{C}$ is $109 \mathrm{~g}$ per $100 \mathrm{ml}$ [35], concentration beyond $100 \% \mathrm{~W} / \mathrm{V}$ leads to viscosity and solubility issues. The highly concentrated solution would be very viscous hence difficult transfer and could lead to greater errors from the total amount of $\mathrm{NaOH}$ in deficit. Consequently, variation of volume was used instead.

Similar to the first experiment, both of the unexpected synthesis phenomena (toluene-insoluble black solids and trace of white water-soluble solid on glassware surface in contact with the diluted reaction mixture) were also observed.

\section{Material characterisation}

Variations on colour and texture were observed among the products from this experiment (Fig. 10). Products 11 and 12 (produced from the reactions using high volume of $\mathrm{NaOH}$ solution) both had much lighter shades of brown colour and fluffy texture, while Products 8-10 appeared dark brown without fluffiness (similar to Products 1-7 from the first experiment).

All products generally followed infrared absorption pattern of fullerenol (Fig. 11). However, some deviations from the characteristic pattern were observed in a similar manner to the first experiment. For Products 8-9, it is suggested that the broad shoulder ranging from 3000 to $2000 \mathrm{~cm}^{-1}$ was associated with $\mathrm{Na}_{2} \mathrm{CO}_{3}$. This is supported by pattern of solids covering the surface of the product observed under SEM (Fig. 12a, b) and the fact that their TGA thermograms (Fig. 13a, b) did not show thermal degradation associated with epoxide functional group (onset temperature around $\left.380^{\circ} \mathrm{C}\right)$.

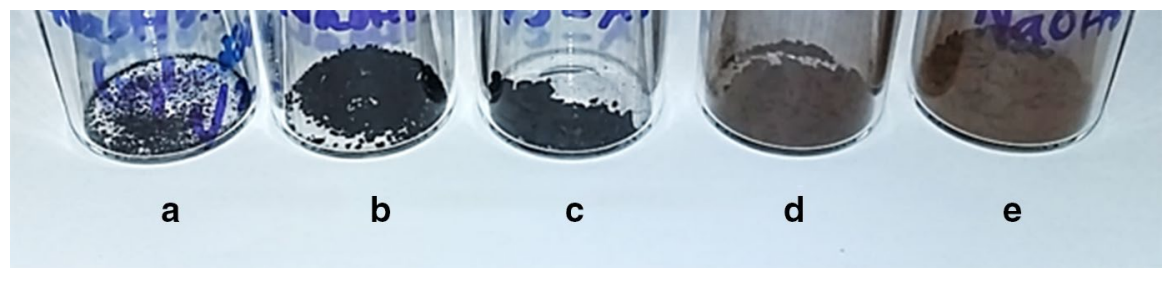

Fig. 10 Physical appearance of Products 8-12 (a-e, respectively) from fullerene hydroxylation using different amounts of $\mathrm{NaOH}$ solution 

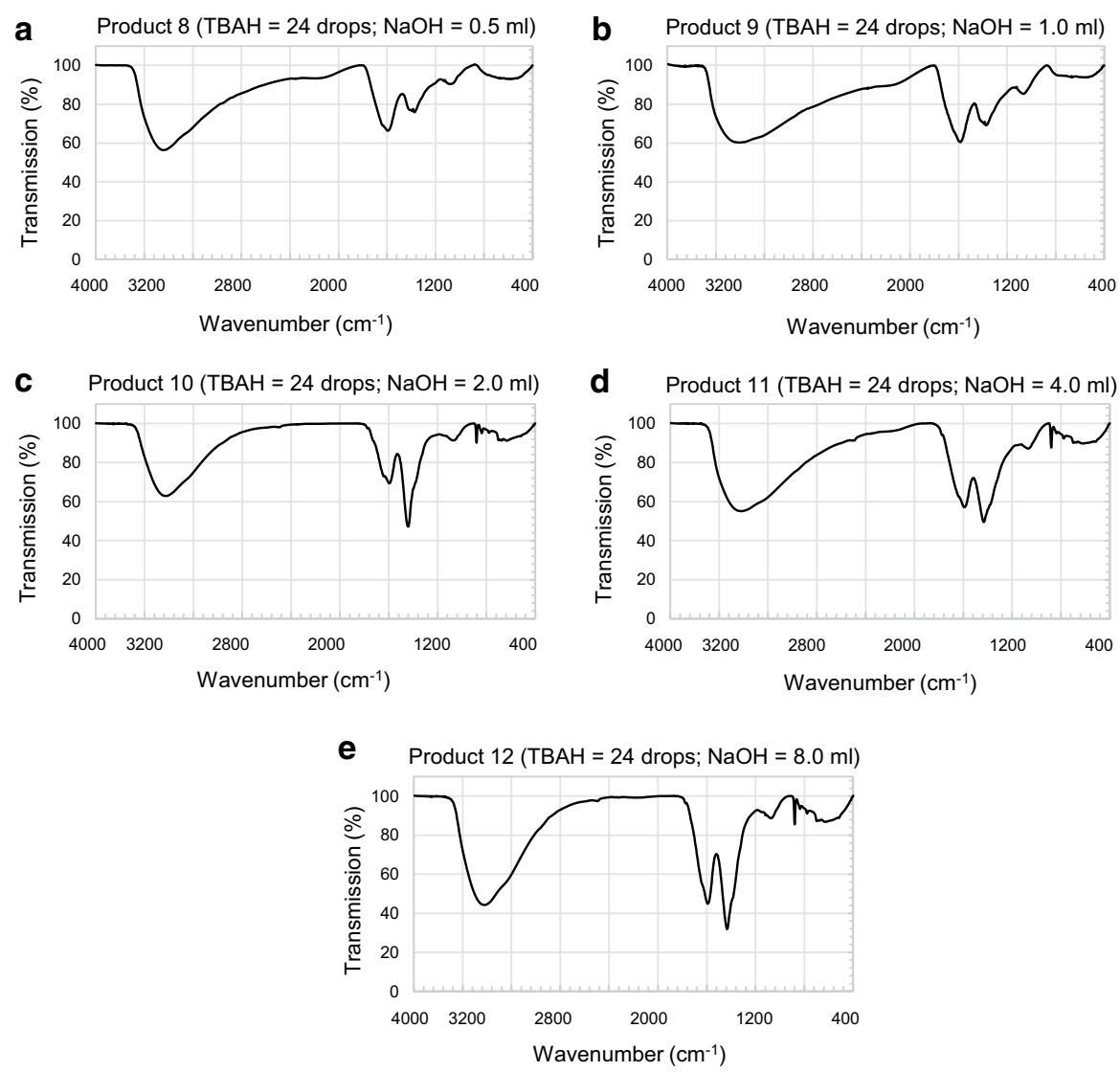

Fig. 11 Infrared spectra of fullerenols synthesised using different volumes of $\mathrm{NaOH}$ solution for the reaction (Products 8-12). All spectra are in transmission mode

In the cases of Products 10-12, the results pointed towards the existence of $\mathrm{Na}_{2} \mathrm{CO}_{3}$ (not incorporated into fullerene structure) and epoxide functionality. In Fig. $11 \mathrm{c}$, d, the $\delta \mathrm{C}-\mathrm{O}-\mathrm{H}$ absorption $\left(1380 \mathrm{~cm}^{-1}\right)$ was almost covered by a strong $1440 \mathrm{~cm}^{-1}$ absorption which was a contribution from $\mathrm{Na}_{2} \mathrm{CO}_{3}$, and the sharp infrared absorption at $880 \mathrm{~cm}^{-1}$ was observed. The strength of the absorption might relate to a high amount of $\mathrm{Na}_{2} \mathrm{CO}_{3}$ existing in the products, considering the amount of needle-like object covering the product surface observed under SEM (Fig. 12c, d) and percentages of elemental composition (Table 4). TGA thermograms of Products 10-12 (Fig. 13c, d) showed clear thermal degradation of epoxide materials.

\section{$\mathrm{NaOH}$ and level of hydroxylation}

Based on the analysis of characterisation results, Products 8-9 were assumed to have chemical formula in the form of ' $a \mathrm{C}_{60}(\mathrm{OH})_{n} \cdot b \mathrm{H}_{2} \mathrm{O}$ with $c \mathrm{Na}_{2} \mathrm{CO}_{3}$ '. With the evidence of epoxide functionality, the model chemical formula for Products 10-12 

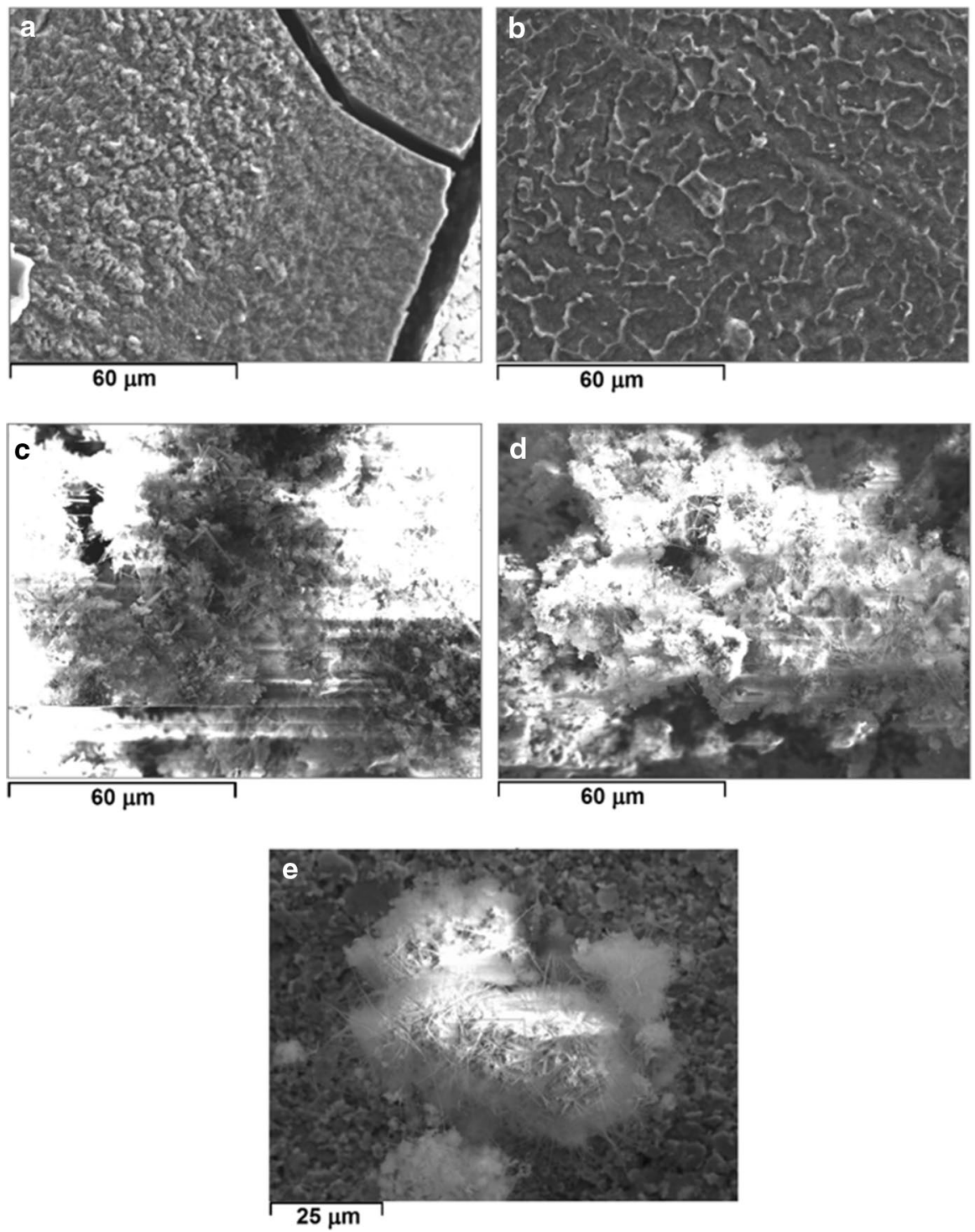

Fig. 12 Low-magnification SEM micrographs of Products 8-12 (a-e, respectively), showing pattern of solids $(\mathbf{a}, \mathbf{b})$ and clear existence of needle-like objects $(\mathbf{c}-\mathbf{e})$ covering the surface of the product

was ' $a \mathrm{C}_{60} \mathrm{O}(\mathrm{OH})_{n} \cdot b \mathrm{H}_{2} \mathrm{O}$ with $c \mathrm{Na}_{2} \mathrm{CO}_{3}$ '. Table 5 displays the calculated chemical formula, along with calculated composition and elemental percentages. Theoretical yield, actual yield and the calculated percent yield of each product are listed in Table 6.

The calculated values for level of achieved hydroxylation (left vertical axis) and percent yield (right vertical axis) were plotted against corresponding amount of 
Table 4 Elemental composition of Products 8-12 obtained from EDX for carbon $(\mathrm{C})$, oxygen $(\mathrm{O})$ and $\operatorname{sodium}(\mathrm{Na})$

\begin{tabular}{lllll}
\hline Product & $\mathrm{NaOH}(\mathrm{ml})$ & $\% \mathrm{C}$ & $\% \mathrm{O}$ & $\% \mathrm{Na}$ \\
\hline 8 & 0.5 & 46.77 & 37.75 & 14.15 \\
9 & 1.0 & 46.76 & 37.57 & 14.97 \\
10 & 2.0 & 37.49 & 42.64 & 19.15 \\
11 & 4.0 & 36.37 & 42.31 & 19.29 \\
12 & 8.0 & 41.29 & 40.71 & 17.73 \\
\hline
\end{tabular}
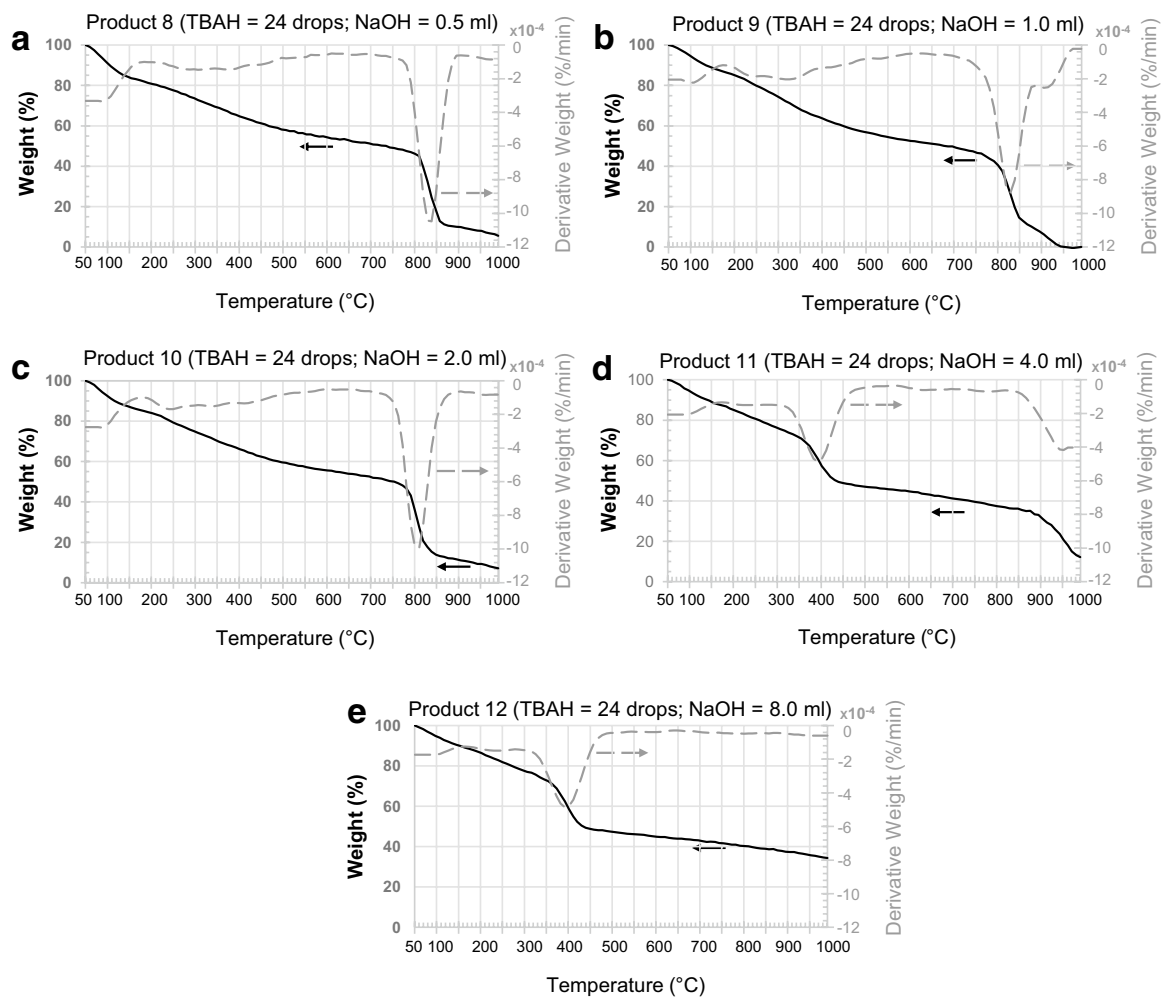

Fig. 13 TGA thermograms of Products 8-12, respectively. The solid black lines represent TGA curves, while the dash grey lines represent the curves of the first derivative (derivative weight)

$\mathrm{NaOH}$ solution used during the synthesis (Fig. 14). Considering the plot of level of hydroxylation (black dots), the average number of hydroxyl groups successfully attached per $\mathrm{C}_{60}$ fullerene molecule initially increased (from 8 to 15 groups) with an increase in the volume of $\mathrm{NaOH}$ solution used for the synthesis from 0.5 to $4.0 \mathrm{ml}$. However, increasing the volume of $\mathrm{NaOH}$ solution for the reaction to $8.0 \mathrm{ml}$ did not raise the level of hydroxylation. Curve fitting was performed on the data set. It was found that the mathematical function of the best fit to the data set $\left(R^{2}=0.9810\right)$ was the following two-term power function: 
Table 5 Calculated chemical formulae for Products 8-12 with corresponding weight percentages of $\mathrm{C}_{60}(\mathrm{OH})_{n}, \mathrm{H}_{2} \mathrm{O}$ and $\mathrm{Na}_{2} \mathrm{CO}_{3}$ components and calculated elemental percentages for $\mathrm{C}, \mathrm{O}, \mathrm{Na}$ and $\mathrm{H}$

\begin{tabular}{|c|c|c|c|c|c|c|c|c|}
\hline Product & Chemical formula & $\%$ wt $\mathrm{C}_{60}(\mathrm{OH})_{n}$ & $\%$ wt $\mathrm{H}_{2} \mathrm{O}$ & $\%$ wt $\mathrm{Na}_{2} \mathrm{CO}_{3}$ & $\% \mathrm{C}$ & $\% \mathrm{O}$ & $\% \mathrm{Na}$ & $\% \mathrm{H}$ \\
\hline 8 & $\begin{array}{l}\mathrm{C}_{60}(\mathrm{OH})_{8} \cdot 17 \mathrm{H}_{2} \mathrm{O} \text { with } \\
\quad 6 \mathrm{Na}_{2} \mathrm{CO}_{3}\end{array}$ & 47.61 & 17.02 & 35.37 & 44.05 & 38.26 & 15.35 & 2.34 \\
\hline 9 & $\begin{array}{c}\mathrm{C}_{60}(\mathrm{OH})_{12} \cdot 12 \mathrm{H}_{2} \mathrm{O} \\
\text { with } 6 \mathrm{Na}_{2} \mathrm{CO}_{3}\end{array}$ & 52.03 & 12.16 & 35.81 & 44.59 & 37.84 & 15.54 & 2.03 \\
\hline 10 & $\begin{array}{c}\mathrm{C}_{60} \mathrm{O}(\mathrm{OH})_{13} \cdot 19 \mathrm{H}_{2} \mathrm{O} \\
\text { with } 10 \mathrm{Na}_{2} \mathrm{CO}_{3}\end{array}$ & 40.57 & 14.50 & 44.92 & 35.61 & 43.73 & 19.50 & 2.16 \\
\hline 11 & $\begin{array}{c}\mathrm{C}_{60} \mathrm{O}(\mathrm{OH})_{15} \cdot 16 \mathrm{H}_{2} \mathrm{O} \\
\text { with } 10 \mathrm{Na}_{2} \mathrm{CO}_{3}\end{array}$ & 42.37 & 12.31 & 45.32 & 35.91 & 42.41 & 19.67 & 2.01 \\
\hline 12 & $\begin{array}{c}\mathrm{C}_{60} \mathrm{O}(\mathrm{OH})_{15} \cdot 13 \mathrm{H}_{2} \mathrm{O} \\
\text { with } 8 \mathrm{Na}_{2} \mathrm{CO}_{3}\end{array}$ & 47.80 & 11.29 & 40.91 & 39.36 & 40.91 & 17.75 & 1.98 \\
\hline
\end{tabular}

Table 6 Theoretical yield (mg), actual yield (mg) and the estimated percent yield for Products 8-12

\begin{tabular}{llllrr}
\hline Product & $\mathrm{NaOH}(\mathrm{ml})$ & Chemical formula & $\begin{array}{l}\text { Theoretical } \\
\text { yield }(\mathrm{mg})\end{array}$ & Actual yield $(\mathrm{mg})$ & \% Yield \\
\hline 8 & 0.5 & $\mathrm{C}_{60}(\mathrm{OH})_{8} \cdot 17 \mathrm{H}_{2} \mathrm{O}$ with $6 \mathrm{Na}_{2} \mathrm{CO}_{3}$ & 193.0 & 7.0 & 3.6 \\
9 & 1.0 & $\mathrm{C}_{60}(\mathrm{OH})_{12} \cdot 12 \mathrm{H}_{2} \mathrm{O}$ with $6 \mathrm{Na}_{2} \mathrm{CO}_{3}$ & 103.1 & 25.2 & 24.4 \\
10 & 2.0 & $\mathrm{C}_{60} \mathrm{O}(\mathrm{OH})_{13} \cdot 19 \mathrm{H}_{2} \mathrm{O}$ with $10 \mathrm{Na}_{2} \mathrm{CO}_{3}$ & 111.0 & 71.0 & 63.9 \\
11 & 4.0 & $\mathrm{C}_{60} \mathrm{O}(\mathrm{OH})_{15} \cdot 16 \mathrm{H}_{2} \mathrm{O}$ with $10 \mathrm{Na}_{2} \mathrm{CO}_{3}$ & 110.5 & 69.7 & 63.1 \\
12 & 8.0 & $\mathrm{C}_{60} \mathrm{O}(\mathrm{OH})_{15} \cdot 13 \mathrm{H}_{2} \mathrm{O}$ with $8 \mathrm{Na}_{2} \mathrm{CO}_{3}$ & 113.0 & 102.7 & 90.9 \\
\hline
\end{tabular}

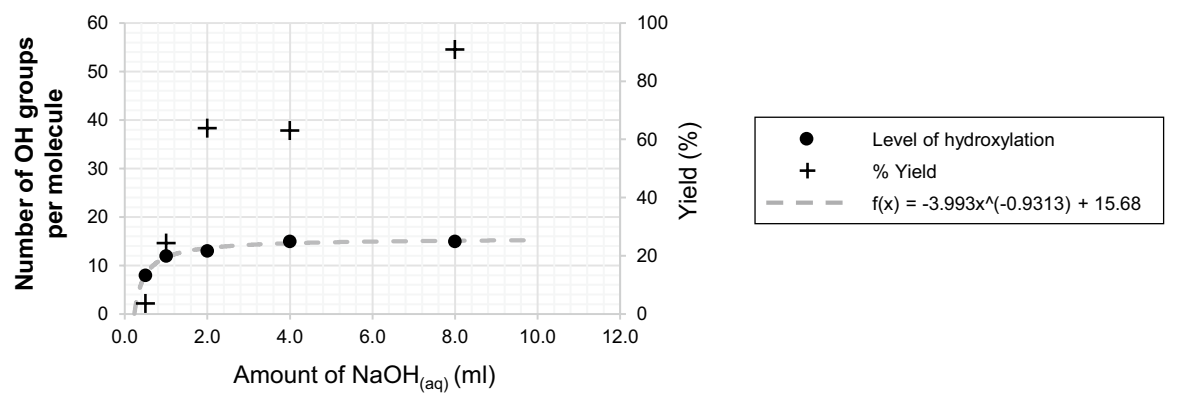

Fig. 14 Plots for level of hydroxylation (dots) and percent yield (crosses) against the amount of $\mathrm{NaOH}$ solution used

$$
f(x)=-3.993 x^{-0.9313}+15.68
$$

During fullerene hydroxylation step, hydroxyl groups in toluene reservoir come into contact with fullerene molecules and form chemical bonds, attaching the hydroxyl groups onto fullerene cages. Supported by the plot of Eq. 7, it is suggested that fullerene hydroxylation could be considered as a liquid-solid 
adsorption process. Freundlich adsorption isotherm (Eq. 8) is often used for the explanation and analysis of such process or system [36]:

$$
C_{\mathrm{s}}^{\prime}=\alpha_{2}\left(C^{*}\right)^{1 / k}
$$

where $C_{\mathrm{s}}^{\prime}$ represents the mass of adsorbate per unit mass of adsorbent, $C^{*}$ refers to concentration of adsorbate in the solution that is in equilibrium with concentration of adsorbate on the solid and $\alpha_{2}$ and $k$ are constants. Equation 7 could therefore be considered as Freundlich adsorption isotherm with an extra term (vertical intercept). More information is required to determine whether the extra term is actually a constant or another parameter particularly for fullerene hydroxylation process. Analysing experimental data from a liquid-solid adsorption process usually require transforming Freundlich adsorption isotherm into the form of Eq. 9 to obtain a linear expression:

$$
\ln \left(C_{\mathrm{s}}^{\prime}\right)=\ln \left(\alpha_{2}\right)+\left(\frac{1}{k}\right) \ln \left(C^{*}\right)
$$

Taking natural $\log$ of the values for level of hydroxylation $(\ln (n))$ and of the values for volume of $\mathrm{NaOH}$ solution used and creating a $\log -\log$ plot result in Fig. 15. Curve fitting was also performed on the data set, resulting in the following expression with its $R^{2}=0.8423$ and shown in Fig. 15 as a dotted line:

$$
f(x)=0.2415 x+2.382
$$

Equation 10 is in agreement with the natural log form of Freundlich adsorption isotherm (Eq. 9). The slope of Eq. 10 can be used to calculate ' $k$ ' constant, and the vertical intercept determines ' $\alpha_{2}$ ' constant of the isotherm for liquid-solid adsorption process. Also, considering the fact that the hydroxyl groups form chemical bonds with the fullerene molecules after hydroxylation reaction, it is suggested that the reaction could be considered a chemisorption type of adsorption.

Fig. 15 Natural log plot (dots) of level of hydroxylation against volume of $\mathrm{NaOH}$ solution used for the process and plot of the fitted linear function $f(x)=0.2415 x+2.382$

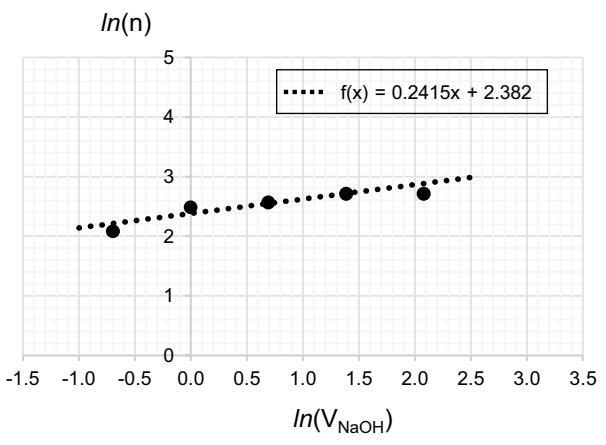




\section{Synthesis abnormalities}

\section{Formation of $\mathrm{Na}_{2} \mathrm{CO}_{3}$ and adverse effect of ambient carbon dioxide $\left(\mathrm{CO}_{2}\right)$ to the selected synthesis method to produce fullerenol}

The trace of white, water-soluble solid was observed throughout the separation steps of each synthesis, on the surfaces which came into contact with the product-containing liquid. The trace was never discovered before toluene removal step of the post-reaction mixture. Considering about when the trace was first discovered during each synthesis, it is suggested that $\mathrm{Na}_{2} \mathrm{CO}_{3}$ was formed as a product of the chemical reaction between ambient $\mathrm{CO}_{2}$ and $\mathrm{NaOH}$ solution:

$$
\mathrm{CO}_{2(\mathrm{~g})}+2 \mathrm{NaOH}_{(\mathrm{aq})} \rightarrow \mathrm{Na}_{2} \mathrm{CO}_{3(\mathrm{~s})}+\mathrm{H}_{2} \mathrm{O}_{(\mathrm{l})}
$$

Due to its higher density, $\mathrm{NaOH}$ solution sank to the bottom of the container, hence totally protected from the external environment by toluene reservoir. Once toluene was removed, the excess of the $\mathrm{NaOH}$ solution in the diluted post-reaction mixture was exposed to and reacted with $\mathrm{CO}_{2}$ in the atmosphere, forming $\mathrm{Na}_{2} \mathrm{CO}_{3}$. Although photographic evidence from SEM showed that $\mathrm{Na}_{2} \mathrm{CO}_{3}$ formed during the synthesis existed as separate entities in the bulk of the collected product, i.e. not chemically bound to fullerenol, this is still a contamination issue which must be avoided from the manufacturing perspective. It is therefore suggested that fullerenol synthesis involving $\mathrm{NaOH}$ solution as the source of hydroxide ions should be operated under $\mathrm{CO}_{2}$-free working environment.

\section{Formation of epoxide functionality and the adverse effect of ambient ozone $\left(\mathrm{O}_{3}\right)$ to the selected synthesis method to produce fullerenol}

Based on the fact that not every product in this research contained characteristic thermal degradation of $\mathrm{C}_{60} \mathrm{O}$ in TGA thermogram, it is believed that the formation of epoxide functional groups within the product was not part of the reaction pathway, but rather caused by external factor(s).

The proper methods to produce $\mathrm{C}_{60} \mathrm{O}$ with reasonable yield generally involve special reaction conditions which were not related or applicable to this research. For instance, the reaction must receive direct and continuous irradiation, or the reaction must be carried out at $-78{ }^{\circ} \mathrm{C}[26,37]$. There are also a few reports on the formation of $\mathrm{C}_{60} \mathrm{O}$ under ambient temperature and pressure, but the reaction must be supplied with a continuous stream of $\mathrm{O}_{3}$-containing $\mathrm{CO}_{2}$ gas [38-40]. Nevertheless, Murdianti et al. [41] have reported on fullerene-water colloidal system as a result of the formation of $\mathrm{C}_{60} \mathrm{O}$ clusters under ambient $\mathrm{O}_{3}$ condition. It is also important to note that, while $\mathrm{C}_{60}$ fullerene dissolves well in toluene, $\mathrm{C}_{60} \mathrm{O}$ is toluene-insoluble $[37,41]$.

The working environment where all syntheses in this research were conducted in the laboratory was located next to an area where there were frequent operations of laser-based instruments (which generates $\mathrm{O}_{3}$ ). It is believed that the 


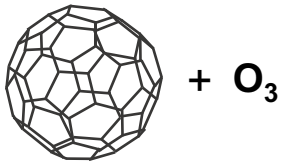

Fullerene

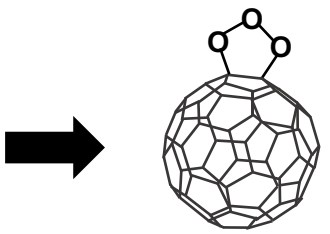

Fullerene ozonide (unstable)
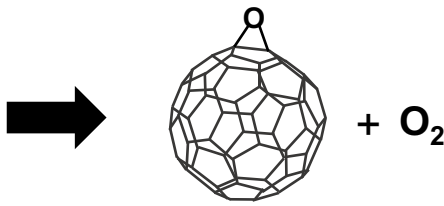

Fullerene epoxide

Fig. 16 Reaction between $\mathrm{C}_{60}$ fullerene and $\mathrm{O}_{3}$ produces fullerene ozonide $\left(\mathrm{C}_{60} \mathrm{O}_{3}\right)$ which is unstable and dissociates into fullerene epoxide $\left(\mathrm{C}_{60} \mathrm{O}\right)$ and oxygen $\left(\mathrm{O}_{2}\right)$. Reprinted (adapted) with permission from Copyright (2000) American Chemical Society [42]

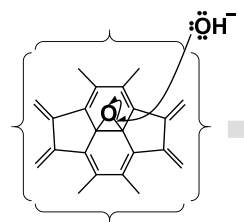

Fullerene epoxide

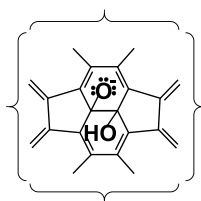

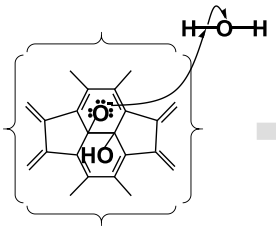

Fullerenol (diol structure)

Fig. 17 Proposed reaction mechanism towards the conversion of $\mathrm{C}_{60} \mathrm{O}$ into fullerenol (diol structure) in an ideal situation where access to the epoxide ring is possible

atmosphere of the laboratory sometimes contained $\mathrm{O}_{3}$ at a level that was sufficient to react with the $\mathrm{C}_{60}$ molecules in the $\mathrm{C}_{60}$-toluene solution. The reaction between $\mathrm{C}_{60}$ and $\mathrm{O}_{3}$ gives the unstable fullerene ozonide $\left(\mathrm{C}_{60} \mathrm{O}_{3}\right)$ which further dissociates into $\mathrm{C}_{60} \mathrm{O}$ and $\mathrm{O}_{2}$ (Fig. 16) [40, 42].

Even though some of $\mathrm{C}_{60}$ molecules were transformed into $\mathrm{C}_{60} \mathrm{O}$, diol structure fullerenol should still be obtained from each $\mathrm{C}_{60} \mathrm{O}$ molecule through a two-step chemical reaction (Fig. 17). Following a nucleophilic attack to the epoxide ring by a hydroxide ion, protonation results in a fullerenol molecule of a diol form. However, the fact that $\mathrm{C}_{60} \mathrm{O}$ thermal degradation was observed in some products indicates otherwise, probably because the hydroxide ions could not reach and react with the epoxide rings.

It is suggested that, once formed inside toluene, $\mathrm{C}_{60} \mathrm{O}$ molecules aggregated and pointed epoxide rings (polar) inward, forming a quasi-polar area within the non-polar reservoir (Fig. 18). According to the study by Dattani et al. [43], progressed aggregation of $\mathrm{C}_{60} \mathrm{O}$ molecules could lead to dense clusters. During the hydroxylation reaction, the reaction mixture was stirred vigorously. Some densely packed clusters might survive the vigorous stirring step, hence their epoxide groups in the quasi-polar area unreachable by the hydroxide ions. However, the desired fullerene hydroxylation still occurred on the surface of $\mathrm{C}_{60}$ molecules, resulting in the formation of hydroxylated fullerene epoxide (or epoxide-containing fullerenol) which was soluble in water and still ended up together with the normal fullerenol. This is another contamination issue which could be more serious than the presence of $\mathrm{Na}_{2} \mathrm{CO}_{3}$, as the epoxide rings are chemically bonded to 
Fig. 18 Clusters of $\mathrm{C}_{60} \mathrm{O}$ molecules (with internal quasi-polar area) formed inside the toluene reservoir prior to the hydroxylation reaction

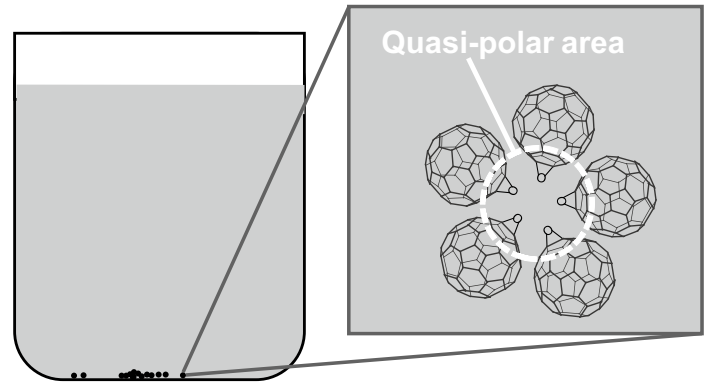

the structure. It is therefore highly recommended to carry out fullerenol synthesis under $\mathrm{O}_{3}$-free area.

\section{Conclusions}

Phase-transfer catalysis with $\mathrm{TBAH}$ and $\mathrm{NaOH}$ solutions is often chosen by several researchers as the method to produce fullerenol. However, the process itself is still not very much understood. This study therefore aimed to gain a better understanding of the reaction and phenomena associated with the process through preliminary experiments on two selected process parameters (amount of TBAH and $\mathrm{NaOH}$ used for synthesis) and the response from the process in terms of the achieved level of fullerene hydroxylation.

In the first experiment (TBAH), it was found that the influence of the amount of TBAH on the achieved level of hydroxylation exhibited a nonlinear behaviour. Although initially showing an upward trend, increasing the amount of TBAH used in the synthesis beyond the local maximum ( 24 drops TBAH, achieving 13 hydroxyl groups) dramatically dropped the achieved level of hydroxylation to a minimum (48 drops TBAH, 8 hydroxyl groups) and similar values. Percent yield of the syntheses from this experiment also followed the same pattern. The second experiment $(\mathrm{NaOH})$ showed an initial increasing trend, followed by a level off after achieving 15 hydroxyl groups from using $4.0 \mathrm{ml} \mathrm{NaOH}$ solution. Curve fitting performed on the data set not only revealed a two-term power function of the $\mathrm{NaOH}$ level of hydroxylation relationship, but also suggested towards Freundlich adsorption isotherm and the fact that the fullerene hydroxylation phenomena in this synthesis method could be considered as and explained by liquid-solid adsorption.

In addition to the intended research objectives, this study has pointed out some problems of the selected synthesis process from the aspect of contamination in fullerenol manufacturing. Ambient $\mathrm{CO}_{2}$ was thought to account for the presence of $\mathrm{Na}_{2} \mathrm{CO}_{3}$ contamination in the bulk of all fullerenol synthesised. Although determined as not chemically bound to the desired fullerenol, $\mathrm{Na}_{2} \mathrm{CO}_{3}$ was still an unwanted contamination which must be separated prior to the intended uses of the produced fullerenol. Another limitation is related to the level of $\mathrm{O}_{3}$ in the working environment which converts $\mathrm{C}_{60}$ (in toluene) into $\mathrm{C}_{60} \mathrm{O}$, hence producing epoxidecontaining fullerenol instead. From a chemistry point of view, a $\mathrm{C}_{60} \mathrm{O}$ molecule 
should still be able to turn into hydroxylated fullerene upon coming into contact with hydroxide ions through the proposed two-step reaction mechanism. Nonetheless, signs of epoxide functionality observed in characterisation results of some of the produced fullerenol indicated otherwise. A proposed explanation was provided, which involved the formation of aggregated $\mathrm{C}_{60} \mathrm{O}$ clusters with quasi-polar area in toluene reservoir. This study therefore suggests for $\mathrm{CO}_{2}$ - and $\mathrm{O}_{3}$-free working environment as precautions for fullerenol manufacturing.

Acknowledgements The authors would like to express their utmost gratitude to Dr Mike Williams, Dr Susan Waring and Peter Wilkinson (Cranfield University, UK) for their generosity in providing access to IR and TGA facilities as well as practical support and useful technical discussions. Dr Ken Mingard (National Physical Laboratory, UK) and Christine Kimpton (Cranfield University, UK) have provided their support on SEM and EDX. Prof Sam Tothill (Cranfield University, UK) provided access to DLS facility. The special acknowledgements are for Prof Ken Kokubo (National Institute of Advanced Industrial Science and Technology, Japan), Prof Colin Webb (University of Manchester, UK) and Prof Arthur Garforth (University of Manchester, UK) for their guidance and meaningful discussion on TGA-elemental analysis and chemical engineering aspects of this research, and to Dr Yi Ge (Queen's University Belfast, UK) for his guidance on practical aspects for fullerenol synthesis.

Funding This research was supported by the Royal Thai Government Scholarship and Cranfield University. Grant number is not applicable in this case.

\section{Compliance with ethical standards}

Conflict of interest The authors declare that there is no conflict of interest.

Open Access This article is licensed under a Creative Commons Attribution 4.0 International License, which permits use, sharing, adaptation, distribution and reproduction in any medium or format, as long as you give appropriate credit to the original author(s) and the source, provide a link to the Creative Commons licence, and indicate if changes were made. The images or other third party material in this article are included in the article's Creative Commons licence, unless indicated otherwise in a credit line to the material. If material is not included in the article's Creative Commons licence and your intended use is not permitted by statutory regulation or exceeds the permitted use, you will need to obtain permission directly from the copyright holder. To view a copy of this licence, visit http://creativecommons.org/licen ses/by/4.0/.

\section{References}

1. H.W. Kroto, J.R. Heath, S.C. O’Brien, R.F. Curl, R.E. Smalley, Nature 318, 162-163 (1985)

2. A. Hirsch, M. Brettreich, Fullerenes: Chemistry and Reactions (Wiley, Weinheim, 2004), pp. 1-48

3. L.Y. Chiang, J.W. Swirczewski, C.S. Hsu, S.K. Chowdhury, S. Cameron, K. Creegan, J. Chem. Soc. Chem. Commun. 62, 24 (1992)

4. L.Y. Chiang, R.B. Upasani, J.W. Swirczewski, J. Am. Chem. Soc. 114, 10154 (1992)

5. J. Li, A. Takeuchi, M. Ozawa, Z. Li, K. Saigo, K. Kitazawa, J. Chem. Soc. Chem. Commun. 256, 822 (1993)

6. L.Y. Chiang, L. Wang, J.W. Swirczewski, S. Soled, S. Cameron, J. Org. Chem. 59, 14 (1994)

7. P. Zhang, H. Pan, D. Liu, Z. Guo, F. Zhang, D. Zhu, Synth. Commun. 33, 14 (2003)

8. G. Zhang, Y. Liu, D. Liang, L. Gan, Y. Li, Angew. Chem. Int. Ed. 49, 31 (2010)

9. K. Kokubo, S. Shirakawa, N. Kobayashi, H. Aoshima, T. Oshima, Nano Res. 4, 2 (2011)

10. S. Chokaouychai, Q. Zhang, Abstract 56th Fullerene-Nanotubes-Graphene General Symposium (2019)

11. T.H. Goswami, R. Singh, S. Alam, G.N. Mathur, Thermochim. Acta 419, 97 (2004) 
12. K. Kokubo, K. Matsubayashi, H. Tategaki, H. Takada, T. Oshima, ACS Nano 2, 2 (2008)

13. R. Chang, K.A. Goldsby, Chemistry (McGraw-Hill, New York, 2016)

14. G.C. Alves, L.O. Ladeira, A. Righi, K. Krambrock, H.D. Calado, R. Pereira de Freitas Fil, M.V.B. Pinheiro, J. Braz. Chem. Soc. 17, 6 (2006)

15. K. Kokubo, in The Delivery of Nanoparticles, ed. by A.A. Hashim (InTech, London, 2012)

16. A.S. Stasheuski, V.A. Galievsky, A.P. Stupak, B.M. Dzhagarov, M.J. Choi, B.H. Chung, J.Y. Jeong, Photochem. Photobiol. 90, 997 (2014)

17. B. Hulliwell, J.M.C. Gutteridge, Free Radicals in Biology and Medicine, 5th edn. (Oxford University Press, Oxford, 2015), pp. 1-29

18. D.B. Min, J.M. Boof, Compr. Rev. Food Sci. Food Saf. 1, 58 (2002)

19. I. Saito, T. Matsuura, K. Inoue, J. Am. Chem. Soc. 103, 188 (1981)

20. R. Bernstein, C.S. Foote, J. Phys. Chem. A. 103, 7230 (1999)

21. A. Greer, Acc. Chem. Res. 39, 11 (2006)

22. A.U. Khan, Photochem. Photobiol. 28, 615 (1978)

23. B.M. Babior, Braz. J. Med. Biol. Res. 30, 141 (1997)

24. P.W. Hart, C. Houtman, K. Hirth, Tappi J. 12, 7 (2013)

25. C.K. Huang, P.F. Kerr, Am. Miner. 45, 311 (1960)

26. K.M. Creegan, J.L. Robbins, W.K. Robbins, J.M. Millar, R.D. Sherwood, P.J. Tindall, D.M. Cox, J. Am. Chem. Soc. 114, 1103 (1992)

27. M. Wohlers, A. Bauer, T. Belz, T. Ruhle, T. Schedel-Niedrig, R. Schlogl, Prepr. Pap. Am. Chem. Soc. Div. Fuel Chem. 41, 108 (1996)

28. D.L. Pavia, G.M. Lampman, G.S. Kriz, Introduction to Spectroscopy, 3rd edn. (Thomson Learning, Boston, 2001)

29. Y.M. Evtushenko, V.M. Ivanov, B.E. Zaitsev, J. Anal. Chem. 58, 4 (2003)

30. M.G. Gonzalez, J.C. Cabanelas, J. Baselga, in Infrared Spectroscopy-Material Science, Engineering and Technology, ed. by T. Theophile (InTech, London, 2012)

31. L.G. Wage, Organic Chemistry, 8th edn. (Pearson, New York, 2014)

32. F. Cataldo, Fuller. Nanotubes Carbon Nanostruct. 19, 4 (2002)

33. L. Weber, Preparations, characteristics, and applications of carbon-based nanomaterials. Thesis. (Technische Universität Ilmenau, Ilmenau, 2009)

34. L.P.F. Chibante, D. Heymann, Geochim. Cosmochim. Acta 57, 8 (1993)

35. Centers for Disease Control and Prevention, CDC-SODIUM HYDROXIDE-International Chemical Safety Cards-NIOSH (CDC, 2017)

36. J.F. Richardson, J.H. Harker, J.R. Backhurst, Particle technology and separation processes, 5 th edn. (Butterworh-Heimann, Oxford, 2002)

37. D. Heymann, B. Weisman, C.R. Chimie 9, 1107 (2006)

38. D. Heymann, L.P.F. Chibante, Recl. Trav. Chim. Pays-Bas 112, 531 (1993)

39. D. Heymann, L.P.F. Chibante, Recl. Trav. Chim. Pays-Bas 112, 639 (1993)

40. D. Heymann, F. Cataldo, Fullerene. Sci. Technol. 9, 1 (2001)

41. B.S. Murdianti, J.T. Damron, M.E. Hilburn, R.D. Maples, R.S.H. Koralege, S.I. Kuriyavar, K.D. Ausman, Environ. Sci. Technol. 46, 7446 (2012)

42. D. Heymann, S.M. Bachilo, R.B. Weisman, F. Cataldo, R.H. Fokkens, N.M.M. Nibbering, R.D. Vis, L.P.F. Chibante, J. Am. Chem. Soc. 122, 11473 (2000)

43. R. Dattani, K.F. Gibson, S. Few, A.J. Borg, P.A. DiMaggio, S.G. Kazarian, J.T. Cabral, J. Colloid Interface Sci. 446, 24 (2015)

Publisher's Note Springer Nature remains neutral with regard to jurisdictional claims in published maps and institutional affiliations. 


\section{Affiliations}

\section{Sirikanya Chokaouychai ${ }^{1,2}\left(\mathbb{D} \cdot Q^{\text {i }}\right.$ Zhang $^{1,3,4}$}

1 School of Aerospace, Transport and Manufacturing (SATM), Cranfield University, Cranfield, Bedfordshire MK43 0AL, UK

2 Present Address: National Science and Technology Development Agency (NSTDA), Thailand Science Park, 111 Phahonyothin Road, Khlong Nueng, Khlong Luang, Pathum Thani 12120, Thailand

3 Present Address: BCMaterials, Basque Center for Materials, Applications and Nanostructures, UPV/EHU Science Park, 48940 Leioa, Spain

4 Present Address: IKERBASQUE, Basque Foundation for Science, 48013 Bilbao, Spain 